\title{
History Through Women's Eyes: The Iowa Women's Archives
}

KAREN M. MASON

\section{Jan 141970}

Dear President Nixon:

My husband and I do not sleep very well these nights, due to the war in Vietnam. When our son left this country last September, he told us we would be very much alone in our worries--that no one really cared about the boys except the boys themselves and their fathers and mothers. We know now what he was talking about. ${ }^{1}$

\section{Peg Mullen wrote these lines to Presi-} dent Richard Nixon just one month before her son Michael was killed by friendly fire in Vietnam. She ended with the plea: "Can someone tell me why we are still in Vietnam?" Mullen had joined Another Mother for Peace the previous month, writing to the organization that ". . I simply cannot live without doing something constructive for peace while my son is fighting as a draftee in Vietnam. I have been against the war from its conception, but my bitterness is increasing rapidly since my 25 year old son is writing his observations and thoughts. ${ }^{2}$

After their son Michael's death on February 18, 1970, Peg and Gene Mullen, of LaPorte City, Iowa, became active opponents of the war in Vietnam. They used his military gratuity pay to

\footnotetext{
${ }^{1}$ Peg Mullen to Richard Nixon, Folder: Correspondence 1970, Box 1, Peg Mullen papers, Iowa Women's Archives, University of Iowa Libraries.

${ }_{2}$ Peg Mullen to Another Mother For Peace, December 16, 1969, Folder: Correspondence 1968-69, Box 1, Peg Mullen papers, Iowa Women's Archives, University of Iowa Libraries.
} 
place a half-page ad in the Des Moines Register on April 12, 1970. The ad consisted of 714 crosses, each one representing an Iowan who had been killed in Vietnam. Across the top of the ad were the lines: "A silent message to fathers and mothers of lowa. We have been dying for nine, long, miserable years in Vietnam in an undeclared war...how many more lives do you wish to sacrifice because of your silence?" The ad generated a great deal of interest within and outside Iowa; interviews with the Mullens were broadcast nationally. The Mullens received hundreds of letters in response to the ad from parents of sons who had also been killed in Vietnam. These letters, along with Peg Mullen's responses to them, form the bulk of her papers at the Iowa Women's Archives. The Peg Mullen papers are an extraordinary source of information for anyone trying to understand the attitudes of Americans toward the war in Vietnam.

The Peg Mullen papers are among the collections that have been donated to the Iowa Women's Archives since its establishment just over a year ago. Quite in contrast to the Mullen papers are the Katharine LaSheck papers, which appeared mysteriously in the archives one day while I was at lunch. LaSheck was a singer and actress who performed with such groups as the College Girls and the Marigold Quartet on the Chautauqua circuit in the early decades of the twentieth century. A native of Iowa City, LaSheck returned here in 1943 to teach voice at the University of Iowa School of Music. The visions called forth by her handwritten sheet music, photographs of costumed actors and actresses, and reviews of performances, help us imagine that we are in the audience at these Chautauqua shows.

The Mullen and LaSheck papers share stack space with a wide variety of collections of personal papers and organizations' records donated by Iowans and former Iowans when they learned of the archives' existence. Mildred Wirt Benson, who wrote the first Nancy Drew mysteries, sent manuscripts and a memory book she compiled while a student at the University of Iowa in the 1920s. Playbills and scrapbooks came 
from Shirley Rich, a casting director who worked for Rodgers and Hammerstein on South Pacific and The King and I before forming her own casting company. Phylliss Henry, who in the 1970s became the first woman assigned to patrol duty on the Des Moines police force, offered documents relating to the sex discrimination she experienced on the job. The diaries of Myrle Olive Ward chronicle her work as a missionary in the West Indies and the Belgian Congo in the 1920s, 1930s, and 1940s. From photographs of television and radio host Mary Jane Odell interviewing Madame Chiang Kai-shek to the mouse-chewed diaries of Laura Gibson Smith, who homesteaded in Wyoming and taught in the Philippines in the early twentieth century, the archives house a remarkable array of documents.

The Louise Noun-Mary Louise Smith Iowa Women's Archives celebrated its opening just over a year ago, on October 28 , 1992, with a symposium on Iowa women in political life. The archives is named for the two women who conceived the idea for this repository of documents on the history of Iowa women and worked to bring it to fruition. Louise Noun is an art collector, historian, and social activist from Des Moines. She is the author of Strong-Minded Women: The Emergence of the Woman-Suffrage Movement in Iowa (1968) and More StrongMinded Women: Iowa Feminists Tell Their Stories (1992). Mary Louise Smith, also from Des Moines, has been active in Republican party politics for many years and was the first (and only) woman to serve as chair of the Republican National Committee, a position she held from 1974 to 1977.

Louise Noun first recognized the need for a repository that would collect material solely on women over two decades ago as she researched the history of women's suffrage in Iowa. Noun experienced the frustration commonly felt by historians; information on some of the more important figures in the movement had vanished. One day over lunch nearly four years ago, Noun and Smith talked about their mutual interest in providing a place to preserve the history of Iowa women. Smith believed that if people knew that there was an archives where women's records would be valued and preserved, they would 
make a deliberate effort to collect materials that might otherwise be lost or destroyed.

Louise Noun and Mary Louise Smith approached University of Iowa President Hunter Rawlings about the need for such an archives and their interest in having it at the university. Rawlings was enthusiastic about the idea, as was University Librarian Sheila Creth, who agreed to find room in the library to house the archives. To make the dream of the archives a reality, Noun offered to sell one of her most treasured paintings, Frida Kahlo's "Self-Portrait with Loose Hair." In May 1991 the painting was sold at auction at Christie's, netting \$1.5 million for an endowment for the Iowa Women's Archives. This endowment, together with additional funds being raised by The University of Iowa Foundation, covered the expense of renovating space in the library and pays the operating costs of the archives.

The mission of the Iowa Women's Archives is to collect, preserve, and make available primary source material on the history of Iowa women. The archives is part of the Special Collections Department at the University of Iowa, but has its own stacks and reading room in the Main Library. The Special Collections Department transferred over thirty processed collections to the Iowa Women's Archives shortly before its opening. The Iowa Women's Archives was fortunate to have this base of collections on which to build, lending the archives credibility and sufficient historical resources to allow the archives to open for research within months of my arrival as curator.

The collections transferred to the Iowa Women's Archives from Special Collections fall primarily into two overlapping subject areas: Iowa women in politics and the women's movement in the late twentieth century. The archives has attempted to build on these strengths in its collecting efforts over the past year. The newly acquired papers of Anna Lomas, for example, join the papers of Mary Louise Smith, Elizabeth Shaw, Charlene Conklin, Patricia Pardun, and Margaret McDonald, to document the expanding role of women in the Republican 
party in recent decades, culminating in the appointment of Mary Louise Smith to the chairmanship of the Republican National Committee in 1974.

Anna Lomas's papers arrived at the archives in robin's egg blue dress boxes and were accompanied by a wealth of political memorabilia, ranging from "I like Ike" buttons to elephant earrings and brooches. Anna Lomas was a Republican national committeewoman for many years; she was an institution in Iowa Republican party politics, as well as an inspiration for Mary Louise Smith. It was not until Lomas stepped aside in 1964 that Mary Louise Smith decided to try for election as a committeewoman. (She won.)

In addition to these collections, the archives holds the papers of Democratic state senator Jean Lloyd-Jones and Democratic state representative Minnette Doderer. The Iowa Women's Archives also holds the records of various political and social reform organizations through which women have been politically active, such as the League of Women Voters, the Iowa Women's Political Caucus, and Church Women United in Iowa. Material documenting the women's movement in Iowa includes the records of several chapters of the National Organization for Women, pro- and anti-ERA organizations, and the rich oral history tapes on which Louise Noun based the stories in More Strong-Minded Women.

Apart from these holdings, the Iowa Women's Archives has developed concentrations in two other areas over the past year. Numerous women journalists are represented in the archives, ranging from Dorothy Pownall, who began her career during World War I reporting on the social aspects of life at Camp Dodge near Des Moines, to Wilma Belden Collins, who edited a two-page weekly paper, the Grimes News, in the late 1940s and early 1950s. Dora Jane Hamblin, a native of Bedford, Iowa, who joined the staff of Life magazine at the end of World War II and more recently wrote for The Smithsonian magazine, donated her papers shortly before her death last summer.

The archives has also begun gathering the records of women's clubs. Many of these acquisitions are small, consisting of 
only an item or two. For example, the Shakespeare Club of Burlington sent a 1992 centennial history and the Daughters of Ceres, an organization of farm women who live near Grimes, Iowa, donated a history compiled for its ninetieth anniversary in 1988. While these single-item donations do not provide as much information as do the complete records of an organization, they give us a sense of the variety of women's associations in Iowa. At the same time, the archives is receiving more substantial collections from other women's organizations and from individuals active in clubs.

The records of the Proteus Club, which was founded in Des Moines in 1896 by seven college graduates intent on continuing their "intellectual improvement", include papers read at the meetings on topics ranging from Mary Wollstonecraft and Indira Gandhi to witchcraft, women's liberation, and Iowa wetlands. Also among the club's records are a recipe box, a cookbook, and a program and photographs of a 1913 skit called "The Militant Husbandette" that parodied the Pankhursts, militant British suffragettes. The records of an Iowa City drama club called Entre Nous and of the Professional Women's League, a Des Moines organization founded in 1900, have recently been added to the archives' holdings in this area.

An east coast reporter who called me shortly before the opening wondered whether in the future I intended to expand the scope of the archives beyond Iowa women, thinking that papers from Iowa women alone would never fill the archives. But the problem for the Iowa Women's Archives is not finding material to collect, but rather deciding how to limit what we collect. This is a problem faced by all archivists. The archives staff is in the process of identifying several areas in which to focus collecting. This collection development policy will build on the existing holdings, such as women in politics, the women's rights movement, and women in journalism, and will in addition identify subjects and groups that are underdocumented or undocumented in the state's repositories. The archives is at present seeking funds to support collecting initiatives to document the history of girls' and women's sports 
in Iowa and of African-American women and their organizations. All collecting areas will undergo periodic review and will undoubtedly evolve over time as research interests change. These areas represent current efforts; no collecting policy should remain static or unexamined.

Although the mission of the archives is to document Iowa women and their organizations, the Iowa Women's Archives is useful not only for studying women's history, but also for contemporary politics, current social issues, and a host of other topics having to do with nineteenth- and twentieth-century life in the United States. Although this is an archives to collect sources on Iowa women, its collections do not deal exclusively with Iowa. Many are focused on Iowa, but not all. Most people do not spend their entire lives in one state; their papers reflect this fact, containing information on what Iowa women did elsewhere. People's lives do not fit neatly within boundaries, whether these be geographical boundaries (such as state lines) or occupational boundaries. Therefore, even though this is the Iowa Women's Archives, it contains a great deal of information about men in Iowa, too. The papers of female legislators, for example, may contain information about the women's issues they supported, but will also contain a great deal of material on issues having nothing to do with gender.

Similarly, family papers may contain diaries, letters, or other items by or about male members of the family. It does not make sense to split the papers into two collections, one to go to the Iowa Women's Archives and one to go elsewhere. If a researcher is interested in studying relations between the sexes, the usefulness of a courting couple's correspondence would be greatly diminished if one half of the letters were held by one repository and the other half by another. Our lives do not divide into tidy categories; neither do the papers we gather or create in the course of living our lives. So the Iowa Women's Archives contains sources for studying men as well as women, and Wyoming and Jamaica as well as Iowa.

The lowa Women's Archives is open to the public and serves the research community at The University of Iowa, graduate 
and undergraduate students, scholars from other institutions, professionals, and individuals conducting research on a variety of topics. It is intended as a resource for all Iowans, not simply the university community. And while most of the users to date have been University of Iowa students, the reading room has also been graced by an adolescent girl doing research on the Nancy Drew series, a teacher working on a supplement to elementary school text books that will focus on Iowa women, and an independent scholar writing a biography of Mary Louise Smith.

Louise Noun has said that "If we do not consciously collect these bits and pieces of Iowa's history as seen through women's eyes, a very valuable part of our state's heritage will be lost." The enthusiastic response to the Iowa Women's Archives in its first year indicates that many Iowans are becoming aware of this heritage and the importance of preserving it. 